\title{
Adaptive hierarchical cell sub-division (AHCS) method for enhanced surface radiance temperature variability analysis
}

\author{
Deepak Kumar ${ }^{1}$ (D)
}

Received: 8 July 2016/Accepted: 11 July 2016/Published online: 21 July 2016

(C) Springer International Publishing Switzerland 2016

\begin{abstract}
The issues with global warming and heat island effect raises the global inclination to elucidate the concerns towards the study of surface temperature variations in the urban environment. Surface radiance temperature (SRT) are considered undeniably one of the most substantial parameters to evaluate the impact of temperature variability in an urban environment. The work tried to present the thermal image processing techniques for retrieving the SRT from Landsat ETM+ data. Afterward, an innovative method namely adaptive hierarchical cell sub-division (AHCS) method in conjunction with statistical techniques were attempted to characterize the spatial variability for each of the directional attributes. These techniques also helped in detecting and quantifying the spatial variability at major and minor scales. The spatial variability through AHCS were analyzed to illustrate their native spatial distribution over urban-rural (Rurban) areas contributing to heat island. The results apparently revealed the aggregate spatial thermal configuration along Rurban areas and vice versa. The key fraction of urban landscape patches with high, sub high and low densities specified their inherent characteristics. The high-temperature type was the prevailing class in the urban core while sub medium temperature and low-temperature type were the main contributors in the rural landscape. Whereas, urban fringe exhibited very complex results of temperature variability for the various land use. The study also authenticated the approach
\end{abstract}

Deepak Kumar

deepakdeo2003@gmail.com

1 Amity Institute of Geoinformatics and Remote Sensing (AIGIRS), Amity University, Room No-05, Ground Floor, J-1 Block, Amity University Campus, Sector 125, Gautam Buddha Nagar, Noida, Uttar Pradesh 201303, India for assimilation of spatial variability techniques with a powerful statistical approach as a reliable instrument to monitor the thermal dynamics.

Keywords Dynamics · Geospatial · Hierarchical · Spatial · Surface $\cdot$ Variability

\section{Introduction}

The rapid advancement and extension in urban development in evolving countries like India is enduring to be one of the key issues of worldwide changes affecting the physical dimensions of cities leading to several changes in their landscape due to upcoming buildings, roads, and other infrastructure replacing all the open land and vegetation cover (Tobergte and Curtis 2005; Urban et al. 2007). There is no sign of decelerating down of this progression. It has become the most powerful and visible anthropogenic force that has brought vital changes in urban land cover and landscape pattern around the country (Moonen et al. 2012). All the surfaces that were permeable and moist become impermeable and dry (Kolokotroni et al. 2010). In this regard, many studies were conducted through the various researchers across the nation including (Dontree 2010) and surface radiance temperature (SRT) were considered as an important indicator for the study of energy balance models on the ground and the greenhouse effect and the main parameters of surface interactions in regional and global scale (Glasbey et al. 2001). Normally SRT can be derived from thermal infrared data supplied by band 6 of the Enhanced Thematic Mapper plus (ETM+) sensor onboard the Landsat 7 satellite. Various algorithms (viz. singlechannel methods, split-window technique and multi-angle methods) have been developed to retrieve SRT from at- 
sensor data and auxiliary data. Surface temperature retrieval depends on the atmospheric effects, the exact amount of emissivity factor and quality of radiation data, including thermal infrared band spectral response function, signal to noise, power and precision of radiometric calibration separation (Li 2004). In the present study, an effort has been taken to utilize the SRT for the study of variability analysis with the help of innovative technic called adaptive hierarchical cell sub-division (AHCS) method. Likewise, statistics techniques augmented the study to provide a set of quantitative tools for detecting and quantifying the spatial variability ranging from major to minor scales (Wilcox and Gueymard 2010). The present study quantified the amount of variability existing the study area through recent techniques.

\section{Materials and methods}

\section{Study area}

The current study has been carried out at Kalaburagi City (formerly known as Gulbarga City) is located at the northern part of the Karnataka State in India. Until very recently, it was a sleepy town having very limited outskirts. The city is located in Northern Part of Karnataka State in India. It lies in the extends between $76^{\circ} 04^{\prime}$ and $77^{\circ} 42^{\prime}$ east longitude, and $17^{\circ} 12^{\prime}$ and $17^{\circ} 46^{\prime}$ north latitude, covering an area of $81-365 \mathrm{~km}^{2}$ from the urban core to outskirts. It is situated in Deccan Plateau and the general average elevation is $454 \mathrm{~m}$ above mean sea level. Black soil is predominant soil type in the district (http://www.gulbarga.nic.in 2015) including city locality. The city is undergoing rapid changes in terms of population growth as well as in the degree of urbanization. The city consists of three main seasons: the summer spanning from late February to mid-June $\left(38-44{ }^{\circ} \mathrm{C}\right)$, followed by the south-west monsoon spanning from the late June to late September with heavy rainfall up to $750 \mathrm{~mm}\left(27-37^{\circ} \mathrm{C}\right)$, and lastly it has dry winter weather until mid-January (11-26 $\left.{ }^{\circ} \mathrm{C}\right) \quad$ (http://www.gulbarga.nic.in 2015), (http:// www.gulbarga.nic.in/ 2016). The main intention behind the selection of the said study area was the author familiarity and accessibility of resources (Fig. 1). The figure shows the orientation and configuration of study area. Inner ring (white in color) shows the urban limits and outer ring (yellow in color) depicts the buffer area.

\section{Datasets and tools used}

The ETM + sensor was an imaging radiometer that measured the amount of reflected and emitted energy from the Earth's surface features in eight regions of the electromagnetic spectrum, ranging from visible to thermal infrared at an 8-bit



Fig. 1 A synoptic view of study area (Landsat ETM+ image), topographic map of the Kalaburagi city and nearby areas along with the structures within it

level. The information of these eight bands is summarized in Table 1. A Landsat 7ETM+ image acquired on December 4, 2000 at approximately 10:30 a.m. has served as the primary data source for driving the whole research work including SRT derivations. Different geospatial software's and tools covering ERDAS 9.2, Arc Desktop 10.x, and ENVI 4.7 were used. The ERDAS software was used for image processing and calibration purposes, Arc Desktop were utilised for mapping and layout purposes. Likewise, the ENVI was utilized for the major of the work including thermal band calibrations and thermal image processing including SRT derivation purposes.

\section{Methodology/theory and computations}

\section{Landsat thermal imagery processing for quantitative analysis}

Many multispectral systems senses radiation in the thermal infrared as well as the visible and reflected infrared portions of the spectrum. However, remote sensing of energy emitted from the Earth's surface in the thermal infrared (3-15 $\mu \mathrm{m})$ is different from the sensing of reflected energy. Multispectral scanning allows the possibility to acquire, display and interpret thermal properties of the Earth's surface (Alipour and Esmaeily 2005). Thermal energy are generally emitted rather than reflected from the Earth's surface. The break in wavelength is at about $3 \mu \mathrm{m}$. Shorter wavelengths are reflected solar energy, whereas longer are emitted from the Earth's surface. The Earth behaves overall as a blackbody with peak energy emission at about 
Table 1 Characteristics of Enhanced Thematic Mapper plus (ETM+) bands

\begin{tabular}{llcccccc}
\hline Band & Spatial resolution $(\mathrm{m})$ & Lower limit $(\mu \mathrm{m})$ & Upper limit $(\mu \mathrm{m})$ & Bandwidth $(\mathrm{nm})$ & Bits per pixel & Gain & Offset \\
\hline 1 & 28.50 & 0.45 & 0.52 & 70 & 8 & 0.786274521 & -6.1999998 \\
2 & 28.50 & 0.53 & 0.61 & 80 & 8 & 0.817254878 & -6.0000000 \\
3 & 28.50 & 0.63 & 0.69 & 60 & 8 & 0.639607867 & -4.5000000 \\
4 & 28.50 & 0.75 & 0.90 & 150 & 8 & 0.939215686 & -4.5000000 \\
5 & 28.50 & 1.55 & 1.75 & 200 & 8 & 0.128470589 & -1.0000000 \\
6 & 57.00 & 10.40 & 12.50 & 2100 & 8 & 0.066823533 & 0.00000000 \\
7 & 28.50 & 2.10 & 2.35 & 380 & 8 & 0.044243138 & -0.3499999 \\
8 & 14.25 & 0.52 & 0.90 & & 8 & 0.786274521 & -6.1999998 \\
\hline
\end{tabular}

$9.7 \mu \mathrm{m}$ wavelength (Jones and Schofield 2008). However, the radiant temperature of a given object depends on many thermal factors, such as emissivity, conductivity, capacity, diffusivity and inertia. Thermal sensors essentially measures the surface temperature and thermal properties of targets (Norman and Becker 1995). For SRT's estimation with only one thermal channel is the main advantage for single-channel methods (Alipour and Esmaeily 2005). Digital numbers can be manually converted to at-sensor radiances, then to brightness temperatures as noted by Klein (2014). This work also intended to advance understanding of thermal imagery.

\section{DN values to absolute radiance conversions}

ETM+ images are acquired in either a low or high gain state. The science goal in switching gain states is to maximize the instrument's 8-bit radiometric resolution without saturating the detectors (Alipour and Esmaeily 2005). This requires matching the gain state for a given scene to the expected brightness conditions. For all bands, the low gain dynamic range is approximately 1.5 times the high gain dynamic range. It makes sense, therefore, to image in the low gain mode when surface brightness is high and in the high gain mode when surface brightness is lower. The perband sensitivity of the instrument is set by adjusting the gain to conditions expected for that time of year. Band gains are set on a month by month basis (Norman and Becker 1995). Bands 1, 2 and 3 are set to high or low gain as a group. Gain settings for bands 5 and 7 are set similarly. Band 6 acquired in both high and low gain mode, while bands 4 and 8 are set individually according to land surface brightness conditions. The DN values of each Landsat image band were scaled from the absolute radiance measure to byte values prior to media output using the gain and bias (offset) values given for each band (Voogt and Oke 2003). Figure 2 describes the complete sequence to derive SRT from thermal infrared image.

The DN values were be converted back to the radiance units using the following equations ( $\mathrm{Li} 2004)$ :

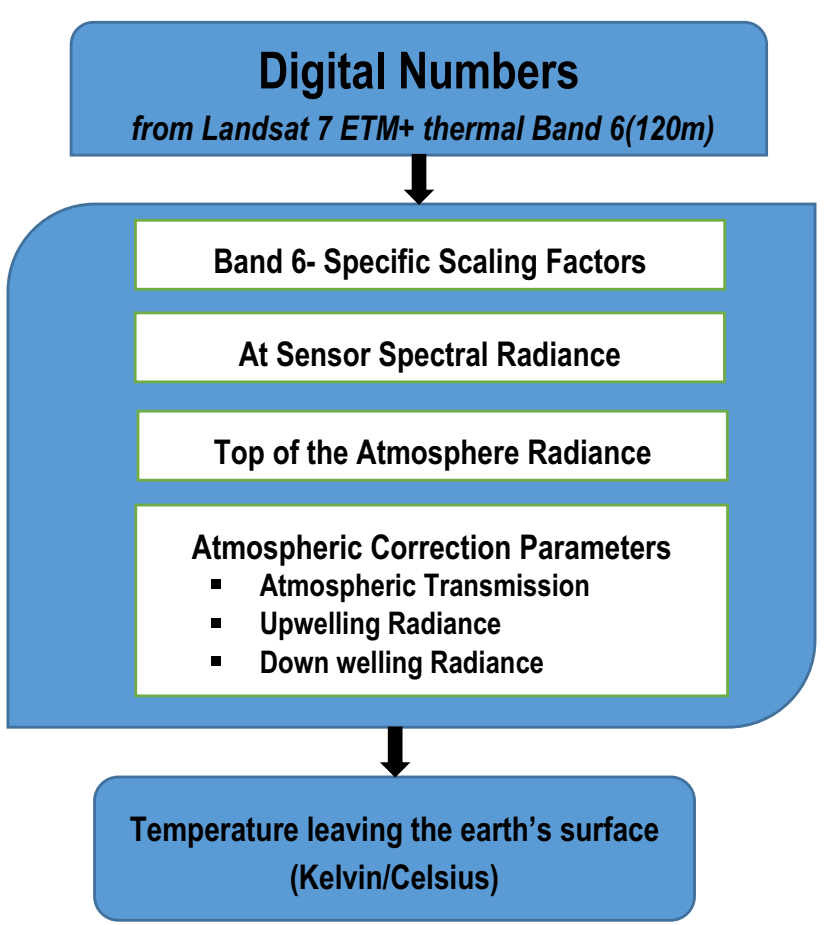

Fig. 2 Workflow to convert satellite images to SRT (flowchart for whole work process). The sketch shows the steps incurred in converting the raw ETM+ thermal Image to the equivalent SRT images

Radiance $=$ gain $\times \mathrm{DN}+$ offset.

Equation (1) can also be expressed as:

$$
\begin{aligned}
\text { Radiance }= & \left(\left(\mathrm{L}_{\text {MAX }}-\mathrm{L}_{\text {MIN }}\right) /\left(\mathrm{Q}_{\text {CALMAX }}-\mathrm{Q}_{\text {CALMIN }}\right)\right) \\
& \times\left(\mathrm{Q}_{\text {CAL }}-\mathrm{Q}_{\text {CALMIN }}\right)+\mathrm{L}_{\text {MIN }},
\end{aligned}
$$

where $\mathrm{Q}_{\mathrm{CALMIN}}=0, \mathrm{Q}_{\mathrm{CALMAX}}=255$ and $\mathrm{Q}_{\mathrm{CAL}}=$ digital number.

The $\mathrm{L}_{\text {MINs }}$ and $\mathrm{L}_{\text {MAXs }}$ are the spectral radiances for each band at digital numbers of $\mathrm{Q}_{\text {CALmin }}$ and $\mathrm{Q}_{\text {Calmax }}$ (for example, $\mathrm{Q}_{\mathrm{CALMIN}}=0$ and $\mathrm{Q}_{\mathrm{CALMAX}}=255$ ). The $\mathrm{L}_{\mathrm{MIN}}$ and $\mathrm{L}_{\mathrm{MAXs}}$ are a representation of how the output Landsat TM Level $1 \mathrm{G}$ data products are scaled in radiance units. 
The $\mathrm{L}_{\mathrm{MIN}}$ corresponds to the radiance at the minimum quantized and calibrated data digital number, $\mathrm{Q}_{\mathrm{CALMIN}}$, and $\mathrm{L}_{\mathrm{MAX}}$ corresponds to the radiance at the maximum quantized and calibrated data digital number, $\mathrm{Q}_{\text {CALMAX }}$. That is, $\mathrm{Q}_{\text {CALMIN }}$ is the minimum number and $\mathrm{Q}_{\text {CALMAX }}$ is the maximum number of each band.

\section{Thermal band calibration constants for ETM+}

Table 2 describes the values of calibration constants, which were used throughout the methods. The ENVI formula in band math for a TM (Barsi et al. 2006) scene will look like:

$$
\text { 1260.56/a log }(666.09 / \mathrm{B} 1+1) \text {. }
$$

In the band pairing dialog B1 is matched with the atmospherically corrected radiance band created.

\section{Radiance to temperature conversions}

TM Band 6 imagery were be converted from spectral radiance (as described above) to a more physically useful variable. This was the effective at-satellite temperature of the viewed earth-atmosphere system under an assumption of unity emissivity and using pre-launch calibration constants listed in Table 2. The conversion formula is:

$T=\frac{K_{2}}{\ln \left(\frac{K_{1}}{L_{\lambda}}+1\right)}$,

where $\mathrm{T}=$ Effective at-satellite temperature in Kelvin, $\mathrm{K}_{2}=$ Calibration constant 2 from Table 2, $\mathrm{K}_{1}=$ Calibration constant 1 from Table $2, \mathrm{~L}_{\lambda}=$ Spectral radiance in watts $/($ meter squared $\times$ ster $\times \mu \mathrm{m})$.

\section{Spatial variation computations for surface temperature}

The surface temperature values at the center of each cell with ' $\mathrm{X}$ ' $\mathrm{km} \times$ ' $\mathrm{X}$ ' $\mathrm{km}$ cell matrix of different cell sizes (i.e. $3 \times 3$ or $5 \times 5$ cell size depending upon the maximum and minimum coverage requirements) can be matched with a neighboring (surrounding the central pixel) cell values to determine the variability, as depicted in Fig. 3.

The schematic diagram shown in Fig. 3 depicts the method used to compare values of center pixel (shown in gray color) with respect to corresponding neighboring cells (i.e. $\Delta_{1}, \Delta_{2}, \Delta_{3} \ldots \Delta_{8}$ or $\left.\partial_{1}, \partial_{2}, \partial_{3} \ldots \partial_{16}\right)$ to compute variation of values at multiple levels. Above-estimated values

Table 2 ETM+ thermal constants and constant value unit

\begin{tabular}{lll}
\hline $\mathrm{K} 1$ & 666.09 & $\mathrm{Wm}^{-2} \mathrm{ster}^{-1} \mu \mathrm{m}^{-1}$ \\
$\mathrm{~K} 2$ & 1282.71 & ${ }^{\circ} \mathrm{K}$ \\
\hline
\end{tabular}

\begin{tabular}{|l|l|l|}
\hline$\Delta_{1}$ & $\Delta_{2}$ & $\Delta_{3}$ \\
\hline$\Delta_{8}$ & & $\Delta_{4}$ \\
\hline$\Delta_{7}$ & $\Delta_{6}$ & $\Delta_{5}$ \\
\hline
\end{tabular}

\begin{tabular}{|l|l|l|l|l|}
\hline$\partial_{1}$ & $\partial_{2}$ & $\partial_{3}$ & $\partial_{4}$ & $\partial_{5}$ \\
\hline$\partial_{16}$ & $\Delta_{1}$ & $\Delta_{2}$ & $\Delta_{3}$ & $\partial_{6}$ \\
\hline$\partial_{15}$ & $\Delta_{8}$ & & $\Delta_{4}$ & $\partial_{7}$ \\
\hline$\partial_{14}$ & $\Delta_{7}$ & $\Delta_{6}$ & $\Delta_{5}$ & $\partial_{8}$ \\
\hline$\partial_{13}$ & $\partial_{12}$ & $\partial_{11}$ & $\partial_{10}$ & $\partial_{9}$ \\
\hline
\end{tabular}

Fig. $33 \times 3$ and $5 \times 5$ grid size layout with anchor cell (at the center) with the surrounding neighbor cells. The figure coveys the schematic and conceptions behind computation of the spatial coefficient of variation (SCOV)

can further calculates the standard deviations of the surrounding cells as:

$\sigma_{s}=\left[\sum_{i=1}^{n}\left(\mathrm{E}_{p} \mathrm{E}_{i}\right)^{2} / n\right]^{1 / 2}$

where $\mathrm{E}_{p}=$ estimated mean, $\mathrm{E}_{i}=$ estimation values, $\sigma_{\mathrm{s}}=$ standard deviation.

Likewise spatial coefficient of variation (COV) were calculated as:

$C_{s}=\sigma_{s} / E_{p}$,

where $C_{\mathrm{s}}=$ spatial coefficient of variation, $\sigma_{\mathrm{s}}=$ standard deviation, $\mathrm{E}_{p}=$ estimated mean.

The similar procedure were applied to derive the SRT within the satellite image with the center of each cell matrix size of $3 \times 3$ or $5 \times 5$ with spatial magnitude of 1 , 2 , or $4 \mathrm{~km}$ for each unit cell. The similar method were also applied to different cell matrix levels to obtain the corresponding values of each pixel locations.

\section{Adaptive hierarchical cell sub-division (AHCS) method}

The proposed AHCS method works on the simple principle of sub-dividing the area on multiple major, minor to micro scales. The complete workflow has been illustrated through the schematics and inscriptions shown in the Fig. 4.

The current study attempted with cell matrix sizes of $3 \times 3$ or $5 \times$ matrix, as shown in Fig. 4 to perform the analysis of the spatial temperature variations ranging from macro to micro level. The whole areas were being divided into smaller cells using the mentioned AHCS method. These each unit of the cell fences $1 \mathrm{~km} \times 1 \mathrm{~km}$, $2 \mathrm{~km} \times 2 \mathrm{~km}$ or $4 \mathrm{~km} \times 4 \mathrm{~km}$ respectively, with a radial extent of 15 and $25 \mathrm{~km}$ from the center of the site. Spatial variability were presented as tables, charts and graphs, and 


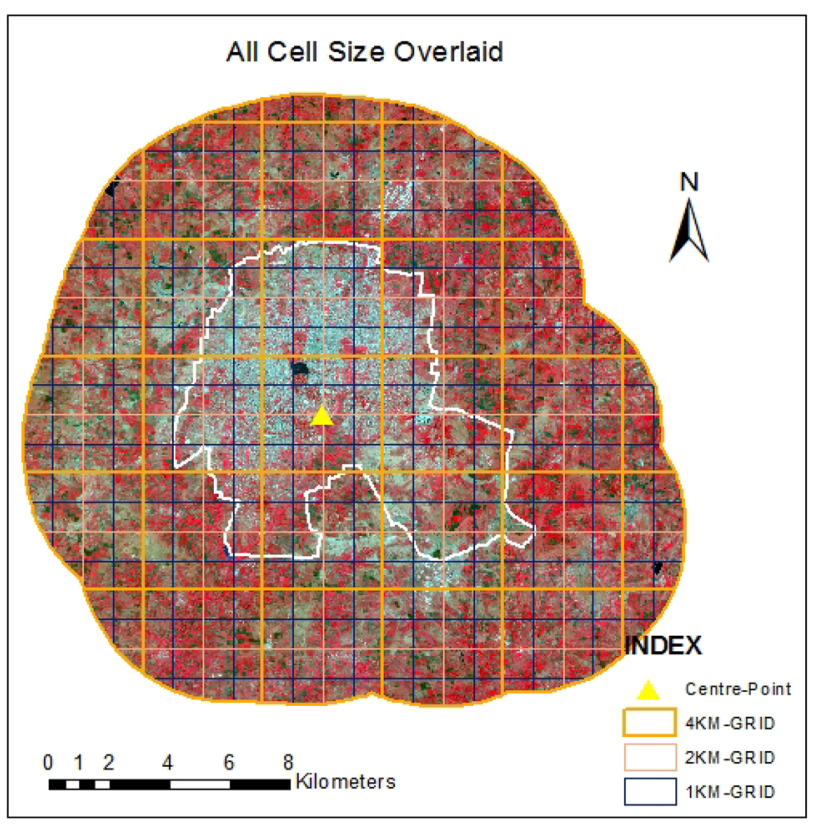

Fig. 4 Schematic for overlay pattern at different cell sizes. The figures exhibits the scheme of overlay patterns of different grid interval size like a $4 \mathrm{~km} \times 4 \mathrm{~km}, \quad$ b $2 \mathrm{~km} \times 2 \mathrm{~km}$ and c $1 \mathrm{~km} \times 1 \mathrm{~km}$

maps to provide a quick visual representation the temperature variations.

\section{Surface radiance temperature variability analysis}

Atmospheric forces and its ingredients have a strong impact on the spatial variability of absorbed, reflected surface radiance temperature reflectance from the earth. The description of the SRT were often not measured in terms of magnitude of surface reflectance at an area of interest over a specific time period, therefore a complete characterization for variability analysis of available surface temperature reflectance at diverse spatial locations is desired. As the knowledge of the resource variability could provide the precarious information for refining the design of a system (by adding properly sized storage capabilities, for instance) and understanding the performance of a solar conversion system (e.g., understanding how the extremes can enhance or degrade system performance or during which season they occur most frequently).

The thermal remote sensing provided the elementary surface temperature data for the spatial variability analysis. The analysis provided the statisticaly derived values for each of the $1 \mathrm{~km} \times 1 \mathrm{~km}, \quad 2 \mathrm{~km} \times 2 \mathrm{~km}$ and $4 \mathrm{~km} \times 4 \mathrm{~km}$ cell sizes. For each of the cell matrix (e.g. 8 for $3 \times 3$ matrix or 24 for $5 \times 5$ matrix) neighboring cell values were used to estimate the coefficient of variation $(\mathrm{COV})$ for cell matrix size of $3 \times 3$ or $5 \times 5$. These values of each cell were also compared with a matrix of surrounding cells to determine the variability of the surface temperature within the matrix, as depicted in Fig. 5a-c and similarly it can be compared in between matrix to perform intensive studies. The mean temperature values $\langle E p\rangle$ along with individual $E_{i}$ value were used to derive the standard deviation of the data set, as per the modified Eq. (5), represented as:

$\sigma_{s}=\left[\sum_{i=1}^{n=8}\left(\mathrm{E}_{p}-\mathrm{E}_{i}\right)^{2} / 8\right]^{1 / 2}$.

Similarly, spatial coefficient of variation (COV) values were also calculated using Eq. 6. These procedures were applied to surface temperature values for each of the cell

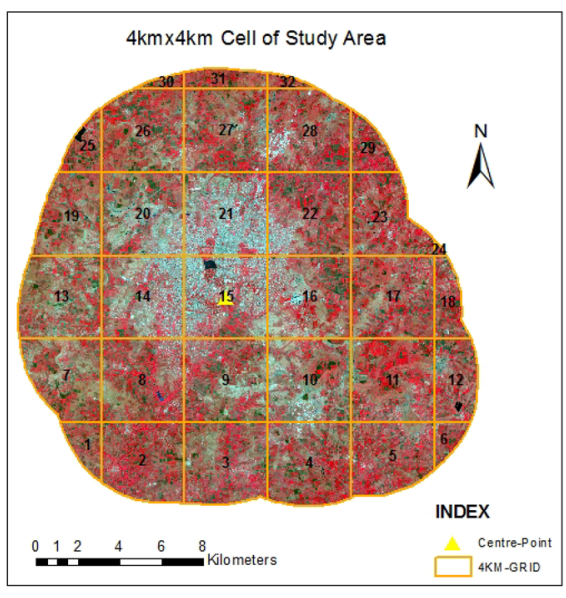

(a) $4 \mathrm{~km} \times 4 \mathrm{~km}$

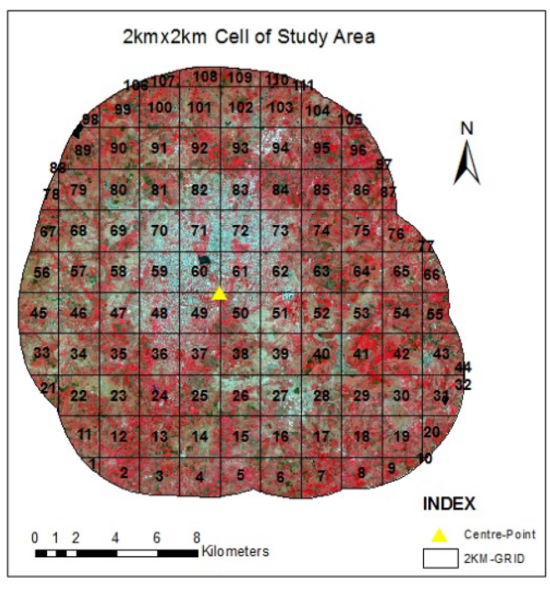

(b) $2 \mathrm{~km} \times 2 \mathrm{~km}$

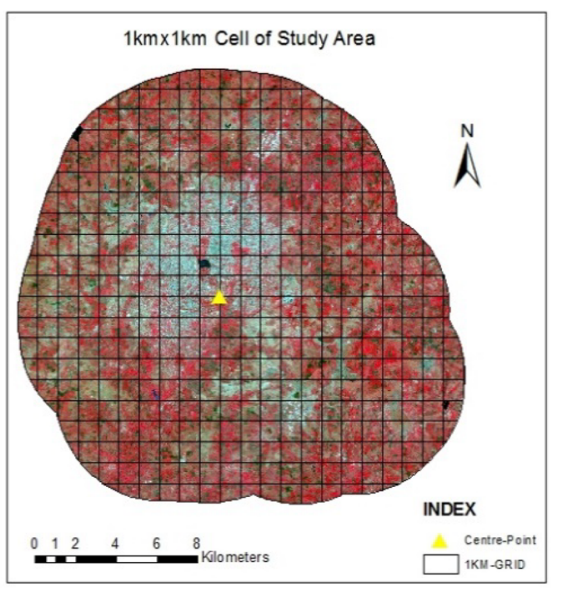

(c) $1 \mathrm{~km} \times 1 \mathrm{~km}$

Fig. 5 Schematic for overlay pattern at different cell sizes viz. a $4 \mathrm{~km} \times 4 \mathrm{~km}, \mathbf{b} 2 \mathrm{~km} \times 2 \mathrm{~km}$ and $\mathbf{c} 1 \mathrm{~km} \times 1 \mathrm{~km}$. This figure exhibits the view of study area overlaid with the grid cells of different sizes 
values. Potential matrix sizes of $3 \times 3$ (for broader coverage) and matrix size $5 \times 5$ (to capture the maximum and minimum areas under the cell) were verified to accommodate the analysis of spatial variation as shown in Fig. 3. Results for spatial variability along with spatial matrixes, were expressed in tabular column. The spatial COV were expressed as ratios between the standard deviation and mean. Figure $5 \mathrm{a}-\mathrm{c}$ illuminates the different arrangements with cell size of $4 \mathrm{~km} \times 4 \mathrm{~km}$ being overlaid to cover the whole area with $3 \times 3$ or $5 \times 5$ cell matrix for sub-division of the complete area into smaller units for easy analysis. The temperature values at center of the each cell location were extracted from the processed thermal imagery. Summary statistics (such as mean and standard deviation) for plotting of the histogram for the further analysis were further computed. By ignores critical information about the spatial location of temperature measurements, the corresponding spatial COV were being computed. Centre are shown by the triangular symbol $(\Delta)$ in Fig. 5.

Tables 3, 4 and 5 summarizes the statistical summary (i.e. min, max, sum, mean, st. deviation along with spatial COV values) for each cell matrix at $4 \mathrm{~km} \times 4 \mathrm{~km}$, $2 \mathrm{~km} \times 2 \mathrm{~km}$ and $1 \mathrm{~km} \times 1 \mathrm{~km}$ grid sizes respectively.

\section{Results and discussions}

\section{Spatial pattern arrangements}

Figure 6a-d demonstrates transects of SRT values in all directions at an interval of $500 \mathrm{~m}$ along all directions for a $12 \mathrm{~km}$ stretch. The variability analysis was aggregated to plot the histogram to compute the corresponding summary

Table 3 Statistical summary of each cell matrix at $4 \mathrm{~km} \times 4 \mathrm{~km}$

\begin{tabular}{|c|c|c|c|c|}
\hline Location & Details & & $\begin{array}{l}\text { Spatial coefficient of } \\
\text { variation }(\mathrm{SCOV})\left(\mathrm{E}_{\mathrm{s}} / \mathrm{E}_{\mathrm{p}}\right)\end{array}$ & Matrix size \\
\hline \multirow[t]{5}{*}{ Upper side } & Min & 24.599218 & 0.09541237 & $3 \times 3$ matrix \\
\hline & $\operatorname{Max}$ & 32.845860 & & \\
\hline & Sum & 264.389694 & & \\
\hline & Mean & 29.376630 & & \\
\hline & St. deviation & 2.802894 & & \\
\hline \multirow[t]{5}{*}{ Lower side } & Min & 24.599218 & 0.07455695 & $3 \times 3$ matrix \\
\hline & $\operatorname{Max}$ & 32.375726 & & \\
\hline & Sum & 261.118465 & & \\
\hline & Mean & 29.013163 & & \\
\hline & St. deviation & 2.163133 & & \\
\hline \multirow[t]{5}{*}{ Right side } & Min & 24.599218 & 0.08748454 & $3 \times 3$ matrix \\
\hline & Max & 32.375126 & & \\
\hline & Sum & 261.539452 & & \\
\hline & Mean & 29.05999 & & \\
\hline & St. deviation & 2.5423 & & \\
\hline \multirow[t]{5}{*}{ Left side } & Min & 24.599218 & 0.07787159 & $3 \times 3$ matrix \\
\hline & Max & 32.375126 & & \\
\hline & Sum & 256.745316 & & \\
\hline & Mean & 28.52257 & & \\
\hline & St. deviation & 2.221098 & & \\
\hline \multirow[t]{5}{*}{ Center of cell } & Min & 24.599218 & 0.07712295 & $5 \times 5$ matrix \\
\hline & Max & 32.84586 & & \\
\hline & Sum & 642.125566 & & \\
\hline & Mean & 29.187526 & & \\
\hline & St. deviation & 2.251028 & & \\
\hline \multirow[t]{5}{*}{ Centre of cell } & Min & 24.599218 & 0.08089155 & $3 \times 3$ matrix \\
\hline & Max & 32.375126 & & \\
\hline & Sum & 262.538179 & & \\
\hline & Mean & 29.170909 & & \\
\hline & St. deviation & 2.35968 & & \\
\hline
\end{tabular}


Table 4 Statistical summary of each cell matrix at $2 \mathrm{~km} \times 2 \mathrm{~km}$

\begin{tabular}{|c|c|c|c|c|}
\hline Location & Details & & $\begin{array}{l}\text { Spatial coefficient of } \\
\text { variation }(\mathrm{SCOV})\left(\mathrm{E}_{\mathrm{s}} / \mathrm{E}_{\mathrm{p}}\right)\end{array}$ & Matrix size \\
\hline \multirow[t]{5}{*}{ Center of cell } & Min & 25.099554 & 0.05697567 & $5 \times 5$ matrix \\
\hline & Max & 31.902706 & & \\
\hline & Sum & 724.068705 & & \\
\hline & Mean & 28.962748 & & \\
\hline & St. deviation & 1.650172 & & \\
\hline \multirow[t]{5}{*}{ North-west } & Min & 25.099554 & 0.05711009 & $5 \times 5$ matrix \\
\hline & Max & 32.375126 & & \\
\hline & Sum & 726.969025 & & \\
\hline & Mean & 29.078610 & & \\
\hline & St. deviation & 1.660682 & & \\
\hline \multirow[t]{5}{*}{ South-east } & Min & 26.588539 & 0.06650049 & $5 \times 5$ matrix \\
\hline & Max & 33.78231 & & \\
\hline & Sum & 739.413309 & & \\
\hline & Mean & 29.576532 & & \\
\hline & St. deviation & 1.966854 & & \\
\hline \multirow[t]{5}{*}{ South-west } & Min & 25.099554 & 0.05590038 & $3 \times 3$ matrix \\
\hline & Max & 32.84586 & & \\
\hline & Sum & 734.7052 & & \\
\hline & Mean & 29.388208 & & \\
\hline & St. deviation & 1.642812 & & \\
\hline \multirow[t]{5}{*}{ North-east } & Min & 26.588539 & 0.06026446 & $5 \times 5$ matrix \\
\hline & Max & 34.248077 & & \\
\hline & Sum & 730.320129 & & \\
\hline & Mean & 29.212805 & & \\
\hline & St. deviation & 1.760494 & & \\
\hline \multirow[t]{5}{*}{ West-left } & Min & 25.099554 & 0.05591236 & $3 \times 3$ matrix \\
\hline & Max & 30.952703 & & \\
\hline & Sum & 253.913389 & & \\
\hline & Mean & 28.212599 & & \\
\hline & St. deviation & 1.577433 & & \\
\hline \multirow[t]{5}{*}{ East-right } & Min & 26.588539 & 0.05977087 & $3 \times 3$ matrix \\
\hline & Max & 31.902706 & & \\
\hline & Sum & 263.110115 & & \\
\hline & Mean & 29.234457 & & \\
\hline & St. deviation & 1.747369 & & \\
\hline
\end{tabular}

statistics. The comparison of standard deviations was useful in predicting temperature variability in different directions within similar types of distances.

Similarly, Table 6 tabulates the descriptive statistics of transects of temperature values in all directions (with $500 \mathrm{~m}$ interval) to provide the synoptic figure of the variability along with trends of variability for all directions. The spatial variability affects the spatial metrics and indices to quantify the amount of variability in diverse dimensions. Accumulation of surface temperature datasets and making them available can be very useful for future use by managers, planners, public health officials, ecologists, and researchers.

The further part of study covered the calculation of intensity or magnitude as ratios or percentages obtained from the several statistical parameters of surface temperature. These indicated that there were prominent temperature variations in urban core area with respect to Rurban areas due to extensive urban advancements. The complexity in temperature trends due to increasing growth from urban center to adjoining rurban non-built up areas in all cardinal directions were also unveiled. The temperature 
Table 5 Statistical summary of each cell matrix at $1 \mathrm{~km} \times 1 \mathrm{~km}$

\begin{tabular}{|c|c|c|c|c|}
\hline Location & Details & & $\begin{array}{l}\text { Spatial coefficient of } \\
\text { variation }(\mathrm{SCOV})\left(\mathrm{E}_{\mathrm{s}} / \mathrm{E}_{\mathrm{p}}\right)\end{array}$ & Matrix size \\
\hline Center & Min & 25.099554 & 0.07194211 & $5 \times 5$ matrix \\
\hline \multirow[t]{4}{*}{ NE (Q1) } & Max & 32.845860 & & \\
\hline & Sum & 719.070173 & & \\
\hline & Mean & 28.762807 & & \\
\hline & St. deviation & 2.069257 & & \\
\hline Upper & Min & 26.588539 & 0.07194211 & $5 \times 5$ matrix \\
\hline \multirow[t]{4}{*}{ NE (Q1) } & Max & 32.845860 & & \\
\hline & Sum & 747.201666 & & \\
\hline & Mean & 29.888067 & & \\
\hline & St. deviation & 26.588539 & & \\
\hline Right & Min & 25.597874 & 0.07786461 & $5 \times 5$ matrix \\
\hline \multirow[t]{4}{*}{ NE (Q1) } & Max & 34.712215 & & \\
\hline & Sum & 741.197786 & & \\
\hline & Mean & 29.647911 & & \\
\hline & St. deviation & 2.308523 & & \\
\hline Centre & Min & 25.597874 & 0.08696648 & $5 \times 5$ matrix \\
\hline \multirow[t]{4}{*}{ SE (Q2) } & Max & 34.712215 & & \\
\hline & Sum & 759.286802 & & \\
\hline & Mean & 30.371472 & & \\
\hline & St. deviation & 2.6413 & & \\
\hline Right & Min & 26.094191 & 0.8181752 & $5 \times 5$ matrix \\
\hline \multirow[t]{4}{*}{ SE (Q2) } & $\operatorname{Max}$ & 34.712215 & & \\
\hline & Sum & 748.348627 & & \\
\hline & Mean & 29.933945 & & \\
\hline & St. deviation & 2.449121 & & \\
\hline Lower & Min & 25.099554 & 0.07191876 & $5 \times 5$ matrix \\
\hline \multirow[t]{4}{*}{ SE (Q2) } & Max & 34.248077 & & \\
\hline & Sum & 744.639191 & & \\
\hline & Mean & 29.785568 & & \\
\hline & St. deviation & 2.142141 & & \\
\hline Centre & Min & 24.096828 & 0.07345099 & $3 \times 3$ matrix \\
\hline \multirow[t]{4}{*}{ SW (Q3) } & Max & 32.375126 & & \\
\hline & Sum & 708.864532 & & \\
\hline & Mean & 28.354581 & & \\
\hline & St. deviation & 2.082672 & & \\
\hline Left & Min & 24.096828 & 0.08658825 & $5 \times 5$ matrix \\
\hline \multirow[t]{4}{*}{ SW (Q3) } & Max & 32.84586 & & \\
\hline & Sum & 730.480164 & & \\
\hline & Mean & 29.219207 & & \\
\hline & St. deviation & 2.53004 & & \\
\hline Lower & Min & 25.099554 & 0.06999316 & $3 \times 3$ matrix \\
\hline \multirow[t]{4}{*}{ SW (Q3) } & Max & 32.84586 & & \\
\hline & Sum & 721.997662 & & \\
\hline & Mean & 28.879906 & & \\
\hline & St. deviation & 2.021396 & & \\
\hline Centre & Min & 21.553249 & 0.099149938 & $5 \times 5$ matrix \\
\hline \multirow[t]{4}{*}{ NW (Q4) } & Max & 33.78231 & & \\
\hline & Sum & 717.724611 & & \\
\hline & Mean & 28.708984 & & \\
\hline & St. deviation & 2.846494 & & \\
\hline
\end{tabular}


Table 5 continued

\begin{tabular}{|c|c|c|c|c|}
\hline Location & Details & & $\begin{array}{l}\text { Spatial coefficient of } \\
\text { variation }(\mathrm{SCOV})\left(\mathrm{E}_{\mathrm{s}} / \mathrm{E}_{\mathrm{p}}\right)\end{array}$ & Matrix size \\
\hline Left & Min & 25.09954 & 0.066428558 & $5 \times 5$ matrix \\
\hline \multirow[t]{4}{*}{ NW (Q4) } & $\operatorname{Max}$ & 33.78231 & & \\
\hline & Sum & 752.864069 & & \\
\hline & Mean & 30.114563 & & \\
\hline & St. deviation & 2.000467 & & \\
\hline Upper & Min & 24.599218 & 0.074079049 & $5 \times 5$ matrix \\
\hline \multirow[t]{4}{*}{ NW (Q4) } & Max & 33.314915 & & \\
\hline & Sum & 742.689398 & & \\
\hline & Mean & 29.707576 & & \\
\hline & St. deviation & 2.200709 & & \\
\hline Centre & Min & 21.553249 & 0.091487128 & $5 \times 5$ matrix \\
\hline \multirow[t]{4}{*}{ NE } & Max & 33.314915 & & \\
\hline & Sum & 698.413267 & & \\
\hline & Mean & 27.936531 & & \\
\hline & St. deviation & 2.555833 & & \\
\hline Centre & Min & 21.553249 & 0.077172035 & $5 \times 5$ matrix \\
\hline \multirow[t]{4}{*}{ NW } & Max & 31.428566 & & \\
\hline & Sum & 681.493629 & & \\
\hline & Mean & 27.259745 & & \\
\hline & St. deviation & 2.10369 & & \\
\hline
\end{tabular}

(a)

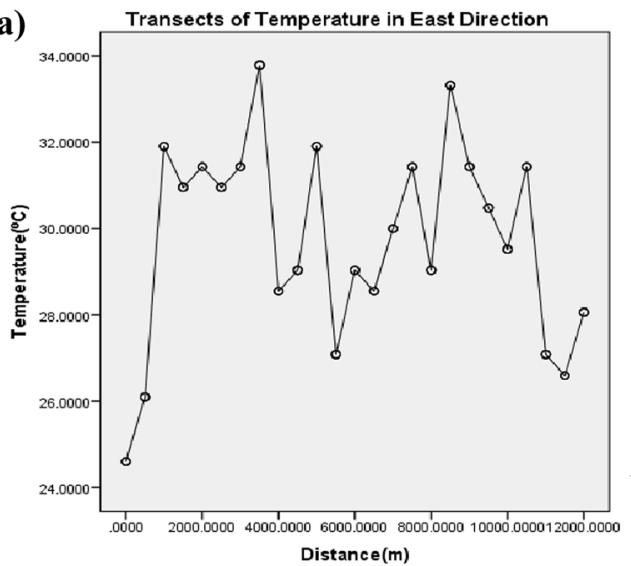

(c)

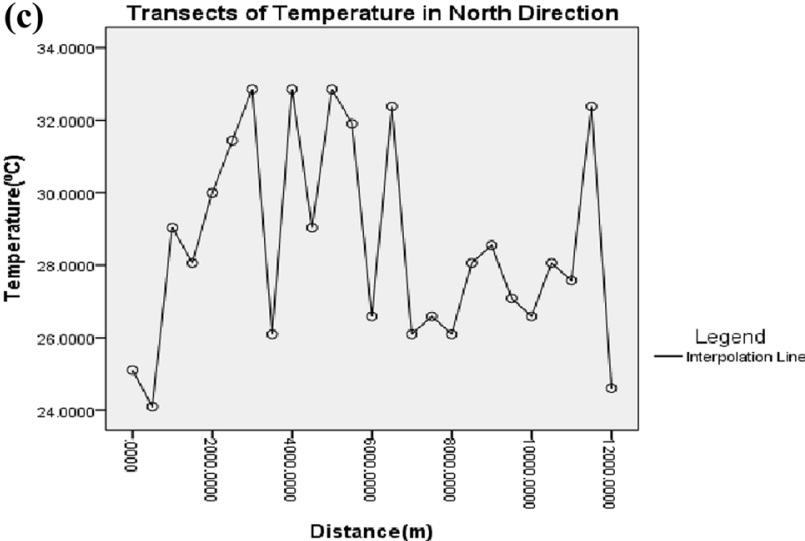

(b)

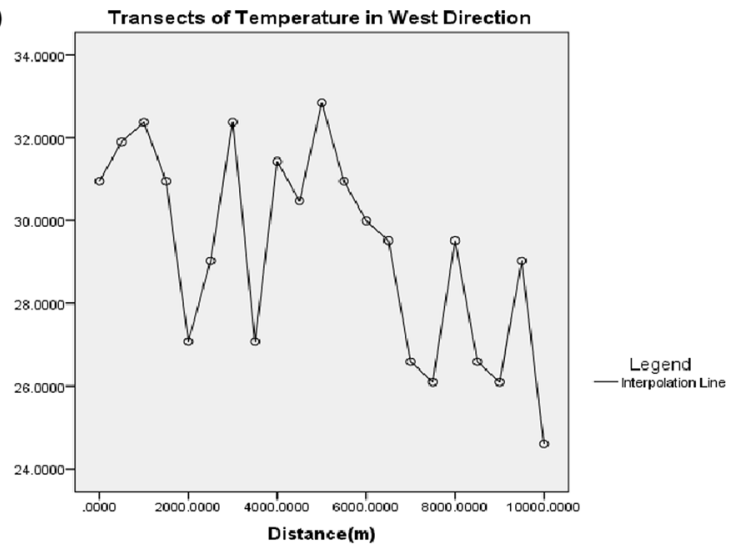

(d)

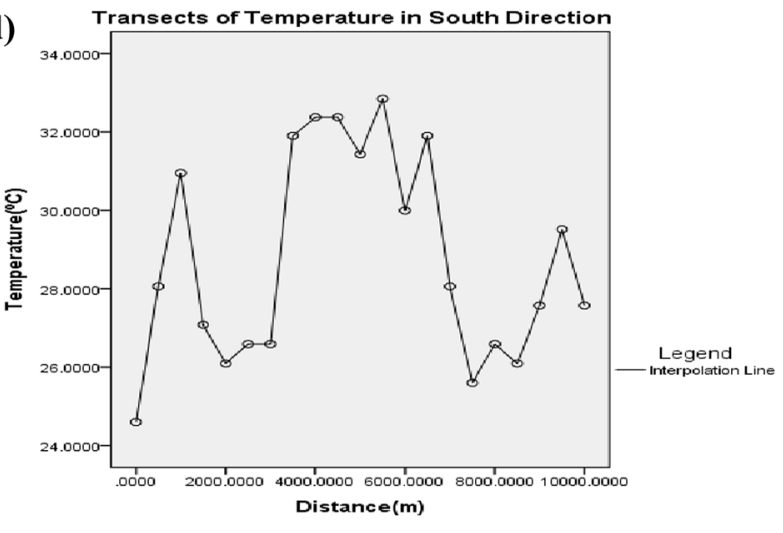

Fig. 6 Transects of temperature profile in all directions (with $500 \mathrm{~m}$ interval).All the figures shows the temperature transects at the interval of $0.5 \mathrm{~km}$ interval in diverse directions from the reference center 
Table 6 Descriptive statistics of transects of temperature values in all directions (with $500 \mathrm{~m}$ interval)

\begin{tabular}{|c|c|c|}
\hline \multirow{2}{*}{$\begin{array}{l}\text { Directions } \\
\text { East }\end{array}$} & \multicolumn{2}{|c|}{ Descriptive statistics (histogram properties) } \\
\hline & Mean & 29.745113 \\
\hline & Std. error of mean & 0.4606106 \\
\hline & Median & 29.995691 \\
\hline & Mode & 31.4286 \\
\hline & Std. deviation & 2.3030532 \\
\hline & Variance & 5.304 \\
\hline & Skewness & -0.387 \\
\hline & Std. error of skewness & 0.464 \\
\hline & Range & 9.1831 \\
\hline & Minimum & 24.5992 \\
\hline & Maximum & 33.7823 \\
\hline \multirow[t]{11}{*}{ West } & Mean & 29.308326 \\
\hline & Std. error of mean & 0.5351656 \\
\hline & Median & 29.514503 \\
\hline & Mode & 30.9527 \\
\hline & Std. deviation & 2.4524369 \\
\hline & Variance & 6.014 \\
\hline & Skewness & -0.333 \\
\hline & Std. error of skewness & 0.501 \\
\hline & Range & 8.2466 \\
\hline & Minimum & 24.5992 \\
\hline & Maximum & 32.8459 \\
\hline \multirow[t]{11}{*}{ North } & Mean & 28.556023 \\
\hline & Std. error of mean & 0.5590500 \\
\hline & Median & 28.059984 \\
\hline & Mode & $26.0942^{\mathrm{a}}$ \\
\hline & Std. deviation & 2.7952499 \\
\hline & Variance & 7.813 \\
\hline & Skewness & 0.308 \\
\hline & Std. error of skewness & 0.464 \\
\hline & Range & 8.7490 \\
\hline & Minimum & 24.0968 \\
\hline & Maximum & 32.8459 \\
\hline \multirow[t]{11}{*}{ South } & Mean & 28.751800 \\
\hline & Std. error of mean & 0.5750869 \\
\hline & Median & 28.059984 \\
\hline & Mode & 26.5885 \\
\hline & Std. deviation & 2.6353792 \\
\hline & Variance & 6.945 \\
\hline & Skewness & 0.239 \\
\hline & Std. error of skewness & 0.501 \\
\hline & Range & 8.2466 \\
\hline & Minimum & 24.5992 \\
\hline & Maximum & 32.8459 \\
\hline
\end{tabular}

${ }^{a}$ Multiple modes exist. The smallest value is shown variabilities were observed to be $20.52-35.64{ }^{\circ} \mathrm{C}$ for the vegetation surfaces and rooftops including open land and built up areas respectively.

\section{Spatial COV characteristics}

This thermal distribution map (in Fig. 7) specifies a wide range of variability existing in the temperature values within the study area, and the values range from insignificant (in the context of measurements and economic analyses) to highly significant.

Figure 8a recognized the values of spatial coefficient of variation $(\mathrm{SCOV})$ obtained through the grid size of $3 \times 3$ cell matrix for the whole area with $4 \mathrm{~km}$ cell size. From the Fig. 8a, it was explained that there was an increase to values of SCOV towards the upper side of the region (towards the north direction from the center) and towards the right side of the region (towards east direction). Apart from these cited locations all other regions had insignificant values of SCOV including the center cell values obtained through the $5 \times 5$ cell matrix. Which established that spatial variation of temperature in the upper (i.e. northern part) and the lower (i.e. southern part) region was greater in compared to the other regions. Also, these can be visually deduced from Fig. 7 that the spatial variation of temperature was more due to the non-homogenous land cover types in these regions and vice versa for the other regions.

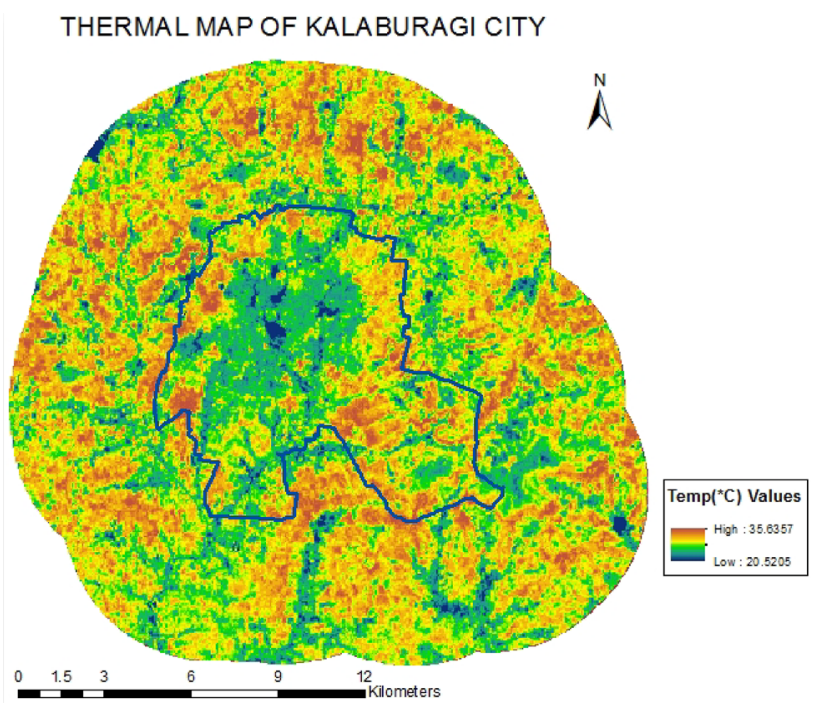

Fig. 7 Temperature distribution map. The current figure indicates the spatial distribution of temperature in color coded form, where deep green (looking blue) signifies the low temperature and red/dark yellow signifies the high temperature values 
Subsequently, Fig. $8 \mathrm{~b}$ exhibited the values of spatial coefficient of variation (SCOV) obtained through the $5 \times 5$ cell matrix grid except West (left) and East (right) regions (where SCOV values have been calculated considering the $3 \times 3$ cell matrix) for the whole area with $2 \mathrm{~km}$ cell matrix size. From the Fig. 8b, it was clear that south-east direction (radially outward from the center towards south-east) showed an increase to values of SCOV and apart from this all other regions have moderate values of SCOV including the West (left) and East (right) cell values obtained in $3 \times 3$ cell matrix. Which inferred that spatial variation of temperature in the south-east region was higher in compared to the other regions. Which can be visually understood from Fig. 7 that spatial variation of temperature is
Fig. 8 Spatial COV curve at different cell matrix levels. The figure illustrates the SCOV distribution curves at different cell matrix levels of like $4 \mathrm{~km} \times 4 \mathrm{~km}, 2 \mathrm{~km} \times 2 \mathrm{~km}$ and $1 \mathrm{~km} \times 1 \mathrm{~km}$

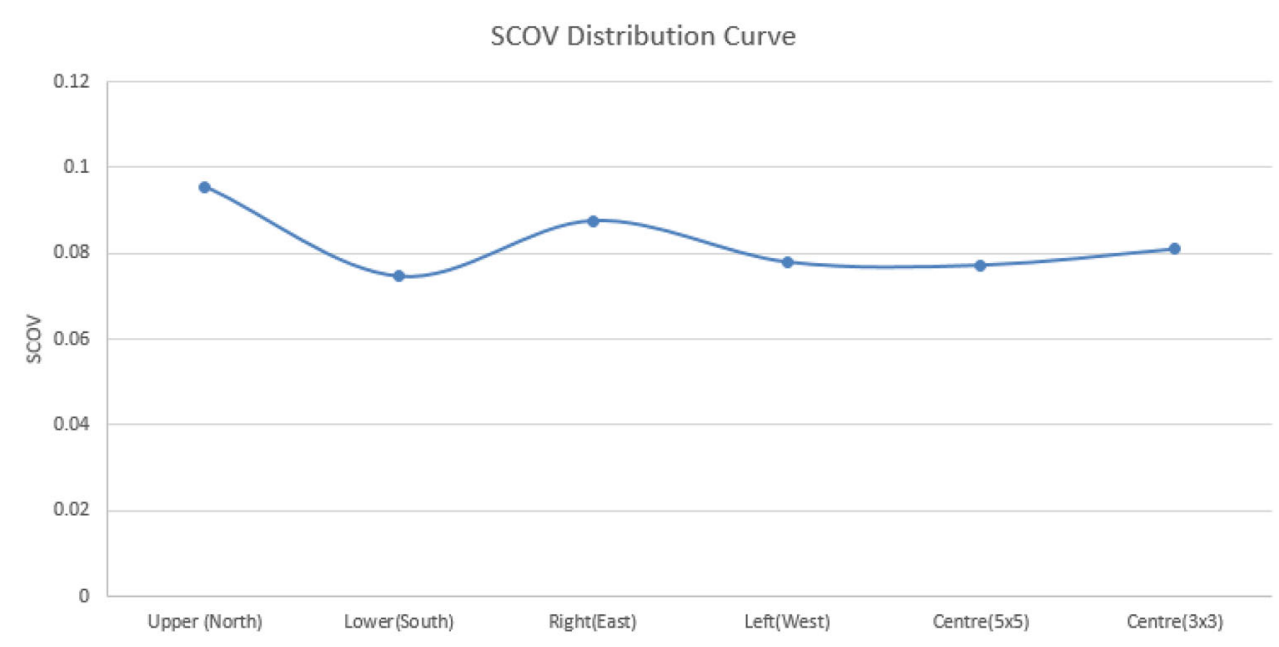

(a) $4 \mathrm{~km} \times 4 \mathrm{~km}$ with $3 \times 3$ matrix

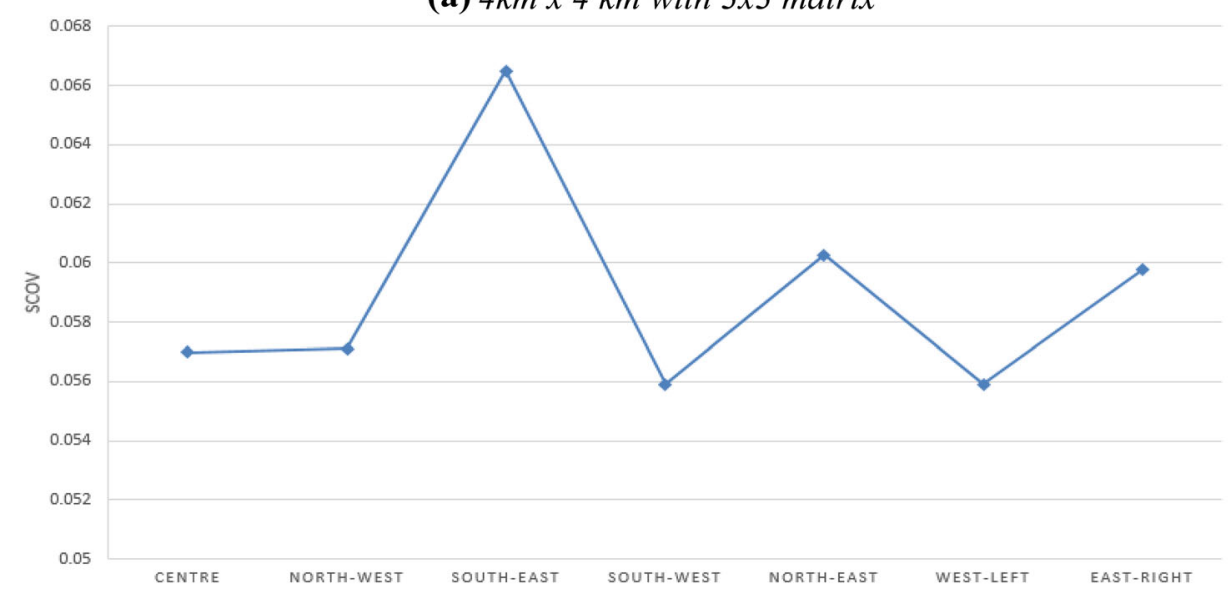

(b) $2 \mathrm{~km} \times 2 \mathrm{~km}$ with $5 \times 5$ matrix SCOV Distribution Curve

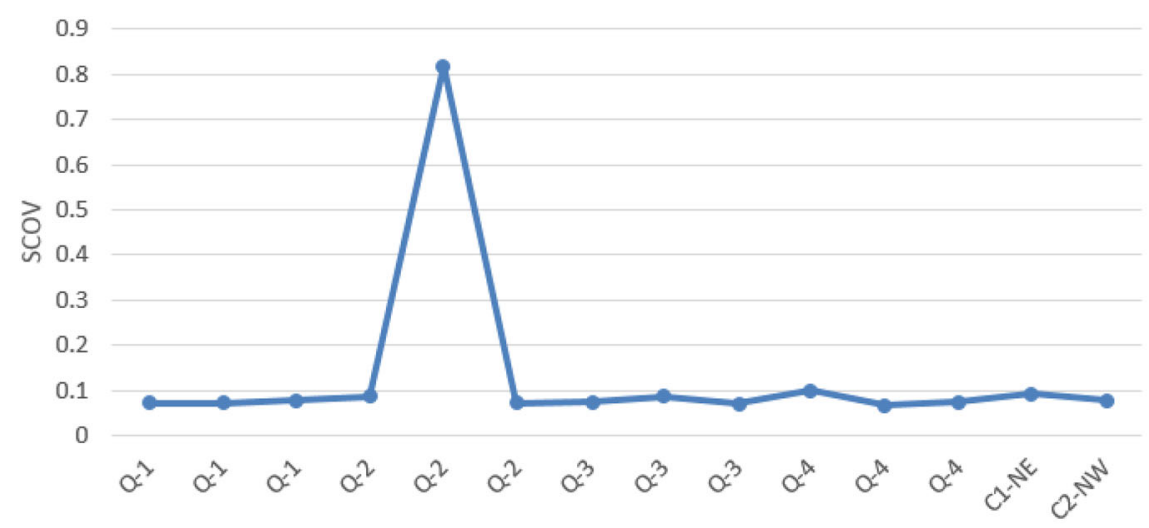

(c) $1 \mathrm{~km} \times 1 \mathrm{~km}$ with $5 \times 5$ matrix 
more due to the non-homogenous type of land cover in the south-east region and vice versa for the other regions.

Figure $8 \mathrm{c}$ fixed the values of spatial coefficient of variation $(\mathrm{SCOV})$ obtained through grid size $5 \times 5$ cell matrix for the whole area with $1 \mathrm{~km}$ size. From the Fig. 8b, c, it can be convened that south-east (right) direction (radially outward from the center towards south-east) showed the prominent increase to values of SCOV and all other regions have minor values of SCOV values obtained in $5 \times 5$ cell matrix. Which inferred that spatial variation of temperature in the south-east (right) region was higher in compared to the other regions. Which can be visually interpreted from Fig. 7 that spatial variation of temperature is more due to the non-homogenous type of land cover in the south-east region and vice versa for the other regions.

\section{Conclusions}

The thermal image processing for surface radiance temperature (SRT) retrieval served as primary method for carrying out the major part of the current work. These SRT image derived were used for AHCS method for enhanced surface radiance temperature variability analysis to understand the extent of dimensions required to characterize the thermal resources for various applications. These are required to address the issues related to the study of surface temperature variations in the urban environment. The work attempted an innovative method namely AHCS method in conjunction with statistical techniques to illustrate the spatial variability in urban scenario. These utilized the generic concepts of statistics and proposed methods. This study also verified that the consistency of the thermal resources (as projected by the temperatures values) in space widely varies across the region. The mapped results illustrated regions with high and low variability along with the quick visual representation to help in decision-making processes for various applications. Lastly, we may conclude that the proposed methods may be also utilized as an effective techniques for evaluating environmental influences (especially thermal influences) for urban ecosystems with the applications of Geospatial Technology.

\begin{abstract}
Acknowledgements The author wish to express gratitude to the research grant received from DST-INSPIRE Division, Ministry of Science \& Technology, Govt. of India for carrying out full time $\mathrm{PhD}$ research work. Author is also thankful to Dr. Sulochana Shekhar, Dean, School of Earth Sciences, Central University of Karnataka for her continuous support \& encouragement and extending the computational \& infrastructural facility.
\end{abstract}

\section{Compliance with ethical standards}

Conflict of interest The authors declare that there is no conflict of interests regarding the publication of this paper.

\section{References}

Alipour T, Esmaeily A (2005) Land surface temperature estimation from thermal band of landsat sensor, case study: Alashtar City. The International Archives of the Photogrammetry, Remote Sensing and Spatial Information Sciences, Vol. XXXVI (2003)

Barsi JA, Hook SJ, Palluconi FD, Schott JR, Raqueno NG (2006) Landsat TM and ETM+ thermal band calibration Space Science and Applications, Inc, NASA/GSFC, Code 614. 4, Greenbelt, MD 20781; NASA/JPL Pasadena, CA 91109; 6296-16 V. 4 (p. 1 of 9)/Color: No/Format: Letter/Date: 7/18/2006 12, 4(1):1-9

Dontree S (2010) Relation of land surface temperature (LST) and land use/land cover (LULC) from remotely sensed data in Chiang Mai-Lamphun Basin. In: SEAGA 2010, Hanoi 23-26 Nov 2010, pp 1-11

Glasbey CA, Graham R, Hunter AGN (2001) Spatio-temporal variability of solar energy across a region: a statistical modelling approach. Sol Energy 70(4):373-381. doi:10.1016/S0038092X(00)00152-3

http://www.gulbarga.nic.in/ (2015). Retrieved August 29, 2014, from http://www.gulbarga.nic.in/

http://www.gulbarga.nic.in/ (2016). Kalaburagi. Retrieved July 18, 2016, from http://www.gulbarga.nic.in/

Jones HG, Schofield P (2008). Thermal and other remote sensing of plant stress. Gen Appl Plant Physiol 34:19-32. http://www. bio21.bas.bg/ipp/gapbfiles/v-34_pisa-08/08_pisa_1-2_19-32.pdf

Klein A (2014) Extracting information from thermal remote sensing data. Lab exercise, pp 1-9 (n.d.)

Kolokotroni M, Davies M, Croxford B, Bhuiyan S, Mavrogianni A (2010) A validated methodology for the prediction of heating and cooling energy demand for buildings within the Urban Heat Island: case-study of London. Sol Energy 84(12):2246-2255. doi:10.1016/j.solener.2010.08.002

Li F (2004) Deriving land surface temperature from Landsat 5 and 7 during SMEX02/SMACEX. Remote Sens Environ 92(4):521-534. doi:10.1016/j.rse.2004.02.018

Moonen P, Defraeye T, Dorer V, Blocken B, Carmeliet J (2012) Urban physics: effect of the micro-climate on comfort, health and energy demand. Front Archit Res 1(3):197-228. doi:10. 1016/j.foar.2012.05.002

Norman JM, Becker F (1995) Terminology in thermal infrared remote sensing of natural surfaces. Remote Sens Rev 12:159-173

Tobergte DR, Curtis S (2005) Financing Urban Shelter. United Nations Human Settlements Programme, vol 1. doi:10.1017/ CBO9781107415324.004

Urban F, Benders RMJ, Moll HC (2007) Corrigendum to "Modelling energy systems for developing countries". Energy Policy 35:4765. doi:10.1016/j.enpol.2007.05.012 [Energy Policy 35:3473-3482 (2007). doi:10.1016/j.enpol.2006.12.025]

Voogt JA, Oke TR (2003) Thermal remote sensing of urban climates. Remote Sens Environ 86:370-384

Wilcox S, Gueymard CA (2010) Spatial and temporal variability of the solar resource in the United States. American Solar Energy Society Conference, $1-8$ 